\title{
Administration of Various Feed Additives on Cholesterol Content of Meat and Fat Abdomen of Local Chicken (Gallus Domesticus)
}

\author{
Ilham ${ }^{1}$, Nurliana $^{2}$, Al azhar ${ }^{2}$, Mira Delima $^{3}$, Sugito $^{2}$ and Samadi ${ }^{*}$ \\ ${ }^{1}$ Magister Program of Veterinary Public Health - Veterinary Faculty, \\ Syiah Kuala University-Banda Aceh \\ 2 Veterinary Faculty, Syiah Kuala University-Banda Aceh \\ ${ }^{3}$ Animal Husbandry Department, Agricultural Faculty, Syiah Kuala University-Banda Aceh \\ *Corresponding author e-mail: samadi177@unsyiah.ac.id
}

\begin{abstract}
Cholesterol consumed more than required body will influence health problem such as arteriosklerosis and finally resulted in coronary hearth. The purpose of this study is to evaluate the concentration of cholesterol and fat abdomen local chicken administrated various levels of feed additives. Totally 200 chicken from growth study were selected for 20 chicken at the age of $90 \mathrm{~d}$ for further cholesterol and fat abdomen analysis. This study was designed by using completely randomized consisting of 4 treatments and 5 replications. Four treatments in this study was administration of feed additives either in the water or in the feed $\left(A_{0}=\right.$ control-vita chick 0.7 gram/liter; $A_{1}=20 \mathrm{ml} /$ liter probio-FM; $A_{2}=0.08 \%$ MOS (mananoligosakarida)/kg in feed and $A_{3}=$ herbal leuser $\mathrm{KI} 5 \mathrm{ml} /$ liter). Variables observed in this study were the content of cholesterol and fat abdomen. All data were statistically analyzed using SPSS and differences between treatments were stated $(P<0.05)$ by using Duncan Multiple Range Test (DMRT). The results of the study indicated that administration of various feed additives significantly effected $(P<0.05)$ on the cholesterol content of breast meat of local chicken. The average of breast meat cholesterol content was $52 \mathrm{mg} / 100 \mathrm{~g}, 44$ $\mathrm{mg} / 100 \mathrm{~g}, 43 \mathrm{mg} / 100 \mathrm{~g}$ and $46 \mathrm{mg} / 100 \mathrm{~g}$ for $\mathrm{A}_{0}, \mathrm{~A}_{1}, \mathrm{~A}_{2}$ and $\mathrm{A}_{3}$ respectively. Administration of administration of various feed additives significantly reduced $(P<0.05)$ the percentage of fat abdomen of local chicken with the percentage of $0.78 \%, 0.36 \%, 0.27 \%$ and $0.42 \%$ for $A_{0}, A_{1}, A_{2}$ and $A_{3}$ respectively. This study concluded that administration various feed additives significantly reduced cholesterol content and the percentage of fat abdomen with the lowest of cholesterol content $43 \mathrm{mg} / 100 \mathrm{~g}$ and the lowest percentage of fat abdomen $0.27 \%$ for prebiotic treatment.
\end{abstract}

Keywords: feed additives, cholesterol, fat abdomen and local chicken

Abstrak. Konsumsi kelesterol lebih tinggi dari yang dibutuhkan oleh tubuh dapat mengakibatkan gangguan kesehatan seperti penyakit aterosklerosis dan akhirnya mengakibatkan penyakit jantung coroner. Tujuan dari penelitin ini adalah mengevaluasi konsentrasi kolesterol dan lemak abdomen pada ayam local yang diberikan berbagai jenis imbuhan pakan. Sebanyak 200 ayam lokal yang digunakan pada penelitian performa diambil sebanyak 20 ekor pada umur 90 hari untuk dianalisa lebih lanjut kandungan kolesterol pada daging dada dan berat serta persentase lemak abdomen. Penelitian ini menggunakan rancangan acak lengkap yang terdiri dari 4 perlakuan dan 5 ulangan. Empat perlakuan dalam penelitian ini adalah penambahan imbuhan pakan baik pada minuman maupun dicampur pada pakan $\left(A_{0}=\right.$ kontrol-vita chick 0.7 gram $/$ liter; $A_{1}=20 \mathrm{ml} /$ liter probio-FM; $A_{2}=$ $0,08 \%$ MOS (manan-oligosakarida)/kg in dalam pakan dan $A_{3}=$ herbal leuser $\mathrm{KI} 5 \mathrm{ml} /$ liter). Variabel yang diamati dalam penelitian ini adalah kandungan kolesterol dan berat serta persentase dari lemak abdomen. Semua data diolah secara statistik dengan menggunakan SPSS, perbedaan antar perlakukan dinyatakan $(P<0,05)$, apabila terdapat perbedaan antar perlakuan dilanjutkan dengan mennggunakan uji lanjut jarak berganda Duncan. Hasil penelitian menunjukan bahwa pemberian berbagai imbuhan pakan dapat menurunkan kadar kolestersol dan berat lemak abdomen secara signifikan $(P<0,05)$. Rata-rata kandungan kolesterol perlakuan adalah $52 \mathrm{mg} / 100 \mathrm{~g}, 44 \mathrm{mg} / 100 \mathrm{~g}, 43 \mathrm{mg} / 100 \mathrm{~g}$ and $46 \mathrm{mg} / 100 \mathrm{~g}$ secara berurut untuk $A_{0}$, $A_{1}, A_{2}$ and $A_{3}$. Penambahan berbagai pakan imbuhan juga menurunkan berat lemak abdomen dengan persentase rata-rata adalah $0,78 \%, 0,36 \%, 0,27 \%$ dan $0,42 \%$ secara berurut untuk $A_{0}, A_{1}, A_{2}$ and $A_{3}$. Dari hasil penelitian ini disimpulkan bahwa penambahan berbagai imbuhan pakan secara signifikan dapat menurunkan kadar kelesterol dan lemak abdomen dengan nilai kolesterol terendah adalah $43 \mathrm{mg} / 100 \mathrm{~g}$ dan persentase lemak abdomen terendah adalah 0,27\% pada perlakuan penambahan prebiotik.

Kata kunci: imbuhan pakan, kolesterol, lemak abdomen dan ayam lokal 


\section{Introduction}

Local chicken meat is one of meat sources to support protein consumption with the level of cholesterol content of $116 \mathrm{mg} / 100 \mathrm{~g}$ of meat (Saidin, 2000). Even though cholesterol was important for human that can be used to synthesis hormone and produce bile acid (Baron and Hylemon, 1997), but excess cholesterol consumption caused bad effect on human health such as arteriosklerosis and finally coronary hearth. According to Gropper et al. (2005) recommendation for cholesterol consumption for human was $300 \mathrm{mg} /$ day. One of the ways to reduce cholesterol content is by application of feed additives to animal feed. The research conducted by administration different kind feed additives have been carried out and most of research were focused on animal performance (Torres-Rodriguez et al., 2007; Nurhayati et al., 2016).

Indonesian law has prohibited to use antibiotic as growth promotor since 1 January 2018. Dibner dan Richards (2005) stated that antibiotics improved resistance of pathogen bacteria and influenced health consumers. Therefore, other feed additives such preprobiotic, phytogenic, enzyme, immune modulator to support animal growth could be used to replace the role of antibiotic (Koenan et al., 2004: Jang et al., 2007; Hartono et al., 2016; Ibrahim et al, 2016). Various feed additives can be used to replace antibiotic since feed additives can improve animal performance by depressing pathogen microbe in the tract digestive of animals. In addition, feed additives such as pre- probiotic also will be able to reduce cholesterol and fat contents in the animals. Wiryawan (2005) stated that organic acids produced by lactic acids bacteria bound biles and crystalized, therefore it cannot be reabsorbed on the body and has to be excreted from body by feces. When the bile acids content reduced in the heart, the body will secrete bile acids by taking cholesterol from bloods and tissues system. This cycles will reduce the content of blood and meat cholesterol in the body.

Researches relating administration of feed additives in animal feed have been intensively conducted for all animal production both ruminant and non-ruminant animals. A lot of research for chicken were focused on broiler with performance parameters as indicators. Limited number studies using local chicken by using health parameters as indicators like cholesterol and fat content. Therefore, this research was required to evaluate some important information by using various feed additives on cholesterol and fat abdomen on local chicken.

\section{Materials and Method}

\section{Animal and Nutrition}

The growth study was conducted at private small animal enterprise Banda Aceh and followed by laboratory analysis for cholesterol at integrated laboratory feed technology and nutrition, Bogor Institute of Agriculture. Fat abdomen measurements were conducted at animal nutrition laboratory, Animal Husbandry Department, Agricultural Faculty, Syiah Kuala University Banda Aceh.

Totally 200 chicken from growth study were selected for 20 chicken at the age of $90 \mathrm{~d}$ for further cholesterol analysis and fat abdomen measurement. For growth study, mixed sex chicken were allocated for 10 DOC per unit $(1 \times 1$ $\mathrm{m})$ with 20 units of litter cages. Chicken were fed ad libitum with commercial feed ( $24 \%$ crude protein, $7,4 \%$ crude fat, $6 \%$ crude fiber, $8 \%$ ash and $3200 \mathrm{kkal} / \mathrm{kg}$ ) and free access of water. The temperature was controlled from $35^{\circ} \mathrm{C}$ at the beginning and reduced up to $24^{\circ} \mathrm{C}$ after 4 weeks. Chicken

\section{Sample Preparation of Breast Local Chicken}

Chicken from each unit of growth study were chosen based on close weight from average weight for cholesterol analysis and fat 
abdomen measurements. Chicken were slaughtered according to animal ethics and dressed for carcass and fat abdomen measurements. The content of breast chicken cholesterol was measured according to Lieberman-Burchard method. The LiebermannBurchard known as acetic anhydride test is applied for the detection of cholesterol. The positive results was indicated by the formation of a green or green-blue color after a few seconds of application test. The concentration of cholesterol in the samples can be measured by using spectrophotometry (Campbell et al., 2005).

Fat abdomen weight was measured by weighting fat around abdomen and the percentage of fat abdomen was calculated based on comparison between fat abdomen and live weight animals multiply 100 (Wintara, 2011)

\section{Statistical Analysis}

This study was designed by using completely randomized consisting of 4 treatments and 5 replications. Four treatments in this study was administration of feed additives either in the water or in the feed $(A O=$ control-vita chick 0.7 gram/liter; $A 1=20 \mathrm{ml} /$ liter probio-FM; $A 2=$ $0.08 \%$ MOS (Mannan-Oligosakarida) $/ \mathrm{kg}$ in feed and $A 3=$ herbal leuser $\mathrm{KI} 5 \mathrm{ml} /$ liter).

Variables observed in this study were the content of cholesterol and fat abdomen. All data were statistically analyzed using SPSS and differences between treatments were stated $(P<0.05)$ by using Duncan Multiple Range Test (DMRT). Statistical model in this study was:

$$
Y_{i j}=\mu+T_{i}+\varepsilon_{i j}
$$

$Y_{i j}$ is the $j^{\text {th }}$ abservation of the $i^{\text {th }}$ treatment $\mu$ is the population mean

$T_{i}$ is the treatment effect of the $i^{\text {th }}$ treatment $\varepsilon_{i j}$ is the random error

\section{Results and Discussion}

\section{Cholesterol Content}

Cholesterol contents of local chicken administrated various feed additives were shown Figure 1. The results of study indicated that local chicken administrated various feed additives (pro- prebiotic and phytogenic) significantly influenced $(P<0.05)$ the content of cholesterol breast local chicken.

In Figure 1 show that probiotic significantly reduced $(P<0.05)$ the content of cholesterol in breast local chicken. Low of cholesterol content in probiotic treatment since probiotic containing lactic acid bacteria such as Bacillus, Lactobacillus, Escherichia, Streptococcus. Several studies indicated that probiotic was able to reduce cholesterol content and triglycerides and had function to maintain health and immune system. Research conducted by Santoso dan Tanaka (1995) concluded that lactic acid bacteria such as Lactobacillus reduced cholesterol content, triglycerides and improved immune system of animals. Mechanism action of BAL to reduce cholesterol content was caused by the action of bile salt hydrolase (BSH) conjugating with bile acids, glycine or taurine separated from steroid to produce free bile acids. BSH enzyme produced conjugated bile acids in the form of free acid cholic slowly absorbed by small intestine, therefore cholesterol total in the body was reduced. Several kinds of BAL had cells bounding cholesterol in the intestine before being absorbed in the body (Surono, 2004; Ooi and Liong, 2010). The Presence of probiotic in small intestine was able to reduce intestinal $\mathrm{pH}$, it is since probiotic produced lactic acids as main metabolism products. Low $\mathrm{pH}$ value in the intestine stimulated secretion of bike acid to neutralize $\mathrm{pH}$. Bile produced in the hearts used cholesterol in the blood resulted in low cholesterol concentration deposited in meat (Hasanuddin et al., 2013). Therefore, low cholesterol content was produced in meat of animal addministrated probiotics. 


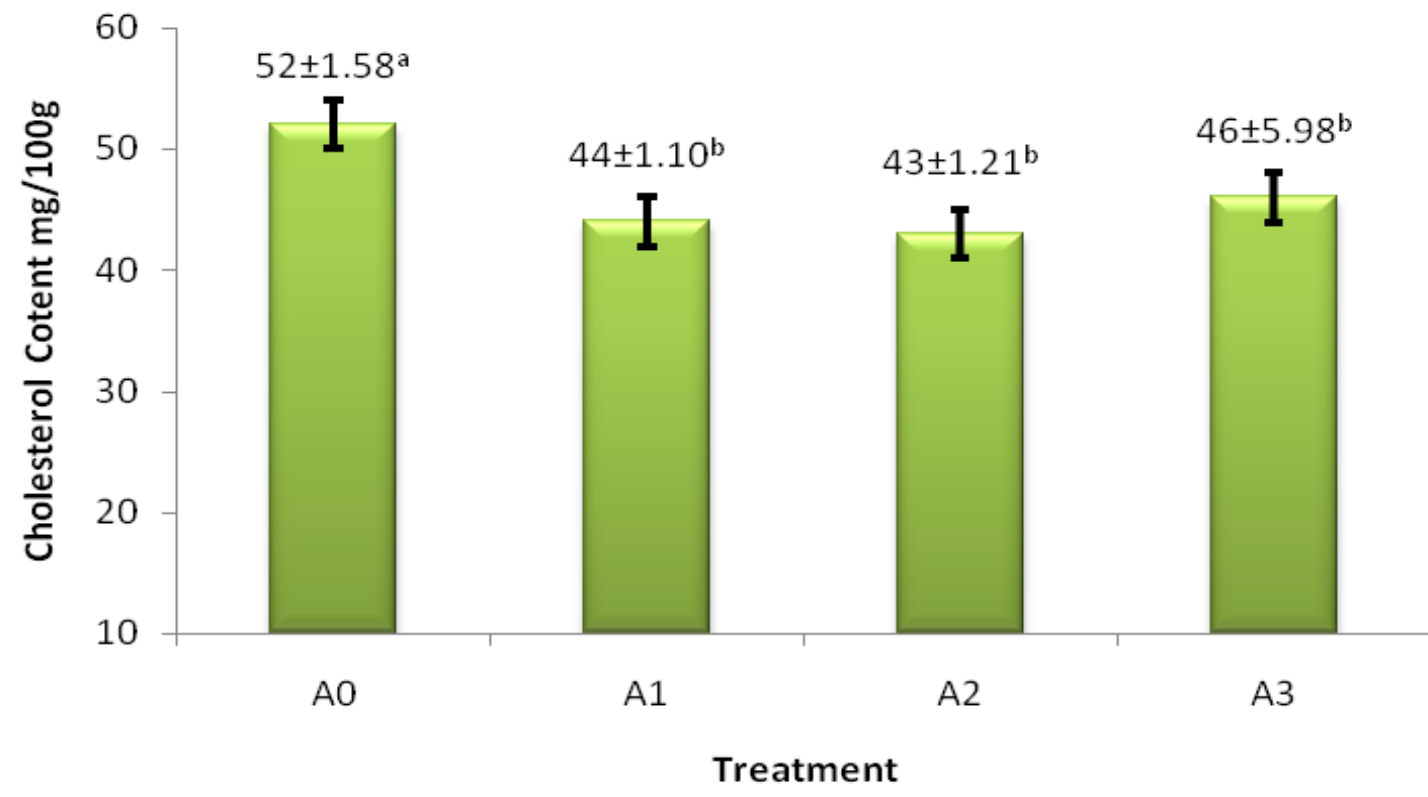

Figure 1. The average of cholesterol $(\mathrm{mg} / 100 \mathrm{~g})$ local chicken administrated various feed additives (pro- prebiotic and phytogenic); $A_{0}=$ control-vita chick 0.7 gram/liter; $A_{1}=20 \mathrm{ml} /$ liter probio-FM; $A_{2}=0.08 \%$ MOS-oligosakarida/ $\mathrm{kg}$ in feed and $A_{3}=$ herbal leuser $\mathrm{KI} 5 \mathrm{ml} /$ liter.

Administration of prebiotic also reduced cholesterol content to $43 \mathrm{mg} / 100 \mathrm{~g}$, it was lower than control (Figure 1). Generally, prebiotic was that feed which cannot be digested by nonruminant animals and had beneficial effects to host by stimulating the growth of several beneficial microbe in the gastrointestinal. Prebiotic categorized as non-digestible carbohydrate and can be as the source of carbohydrate for beneficial bacteria in the gastro intestinal (Crittenden, 1999). Research conducted by Sutama et al (2010) indicated that low content of cholesterol in animals fed prebiotic in the diet resulted in improving crude fiber, therefore flow rate of feed in the intestine was faster and reduced feed digestibility. Crude fiber also increased the production of bile and eliminated the bile production in the faces, therefore heart secreted bile acids in the body as results of bile loss in the feces (Sitepoe, 1993). According to Linder (1992) the process of absorption bile acids and cholesterol from digestive tracts depending on food fiber since fiber food can disturbed re-absorption of cholesterol and bile acids. Therefore, feces excretion with bile elements such as cholesterol was increased.
The higher of fesses excretion was the lower of cholesterol produced by hearts cells.

Local chicken administrated by phytogenic (herbal lauser) in feed significantly reduced $(P<0.05) \quad$ the content of cholesterol to 46 $\mathrm{mg} / 100 \mathrm{~g}$ compared to control. Herbal lauser contains curcumin causing the reduce of cholesterol level in breast meat of local chicken. Research relating to herbals have been intensively conducted. Febrisantosa et al. (2012) stated that application of Ganoderma lucidum powder combined with probiotic reduced fat content and cholesterol in meat. Herbal lauser contain vitamin, mineral and curcumin. Curcumin contains bio-active compound and can be found in turmeric and Curcuma zanthorrhiza. Curcumin has colagoga activities which is able to secrete biles to increase bile acid in the duodenum. It resulted in the production of cholesterol was reduced. Cholesterol was one of metabolic products from biles, the more biles produced ware the more cholesterol used to produce biles (Purseglove et al., 1981). Research conducted by Mide (2007) using rizhome of Curcuma zanthorrhiza in the feed significantly reduced not only abdomen fat but cholesterol in blood chicken as well. Decreasing of abdomen fat and cholesterol was 
caused by excretion of biles acid and cholesterol together with feces and as result in reducing of cholesterol in blood (Mangisah, 2003).

\section{The weight of fat abdomen and the percentage of fat abdomen}

The results of administration various feed additives on the weight of abdomen fat and the percentage of abdomen fat were presented in the Table 1 . The results of the study indicated that administration of various feed additives (pro-, pre biotic and herbal) significantly influenced $(P<0.05)$ the weight of abdomen fat and the percentage of abdomen fat. Table 1 showed that mean values of the weight of abdomen fat were between 2.81 to $8.18 \mathrm{~g}$. The lowest mean value of the weight of abdomen fat was $2.81 \pm 1.27 \mathrm{~g}$ with the treatment of prebiotic administration and the highest was in control with the mean value of $8.18 \pm 2.50 \mathrm{~g}$. The mean value of abdomen fat by administration of probiotic $20 \mathrm{ml} / \mathrm{L}$ was $3.59 \pm 0.34 \mathrm{~g}$ and by administration herbal lauser was $4.06 \pm 0.55 \mathrm{~g}$.

Probiotic is as lactic acid bacteria has an important role to reduce local chicken's meat fat. BAL produced lactic acids in digestive tracts and decreased $\mathrm{pH}$ of digestive tracts around 5 to 6. It will improve feed digestibility and reduced energy production. Furthermore, it will give effect to hamper energy production. Ihsan (2006) stated that lower abdomen fat in the local chicken in the probiotic treatment was a result of production of lactic acid from probiotic bacteria hindered energy production mainly in glycolysis process. In this process, triglyceride and Acetyl-CoA as main component of body lipid biosynthesis including abdomen fat were decreased. According to Fontana et al. (1993) abdomen fat increased in chicken fed low protein and energy feed. Excess energy will be deposited in the form of adipose tissues. One of the parts for fat deposition in the animal body was abdomen. Synthesis of abdomen fat influenced either energy in feed or live weight of animals. Gultom et al. (2012) stated that abdomen fat tented to increase with the heavy body weight.

Abdomen fat was also effected by crude fiber consumption (1992). Crude fiber from prebiotic added in feed improved bile acids at the digestive tracts. By bounding of bile acids resulted in absorbing of fat was hampered. Then, bile acids bound to crude fiber ware excreted with the feces and reduced abdomen fat (Poendjiadi, 2005 dan Akhadiarto, 2010). This was why in our study, administration of prebiotic was the lowest of abdomen fat compared to other treatments. Treatment of herbal lauser containing curcumin also had an important role to reduce abdomen fat. Curcumin stimulated antibacterial in the bile walls, in which bile acids accelerated lipid metabolism. Liang et al, (1985) informed that curcumin had a role to reduce body fat since fat excreted from body though bile secretion and pancreas. In addition, Gultom et al. (2012) stated that fat accumulation in the abdomen fat and absorption from parts of body was influenced by feed. Composition of feed was factors influencing fat in the body. Synthesis of abdomen fat in the body was also due to excess energy consumption (Setiawan dan Sujana, 2009).

Table 1. The average of the weight of abdomen fat and the percentage of abdomen fat was administrated various feed additives

\begin{tabular}{ccc}
\hline Treatment & average (g) & Percentage (\%) \\
\hline A0 (control) & $8.18 \pm 2.50^{\mathrm{a}}$ & $0.78^{\mathrm{a}}$ \\
A1 & $3.59 \pm 0.34^{\mathrm{b}}$ & $0.36^{\mathrm{b}}$ \\
A2 & $2.81 \pm 1.27^{\mathrm{b}}$ & $0.27^{\mathrm{b}}$ \\
A3 & $4.06 \pm 0.55^{\mathrm{b}}$ & $0.42^{\mathrm{b}}$ \\
\hline
\end{tabular}

Mean values (five replicates \pm SEM) with different superscripts within columns are significantly different 


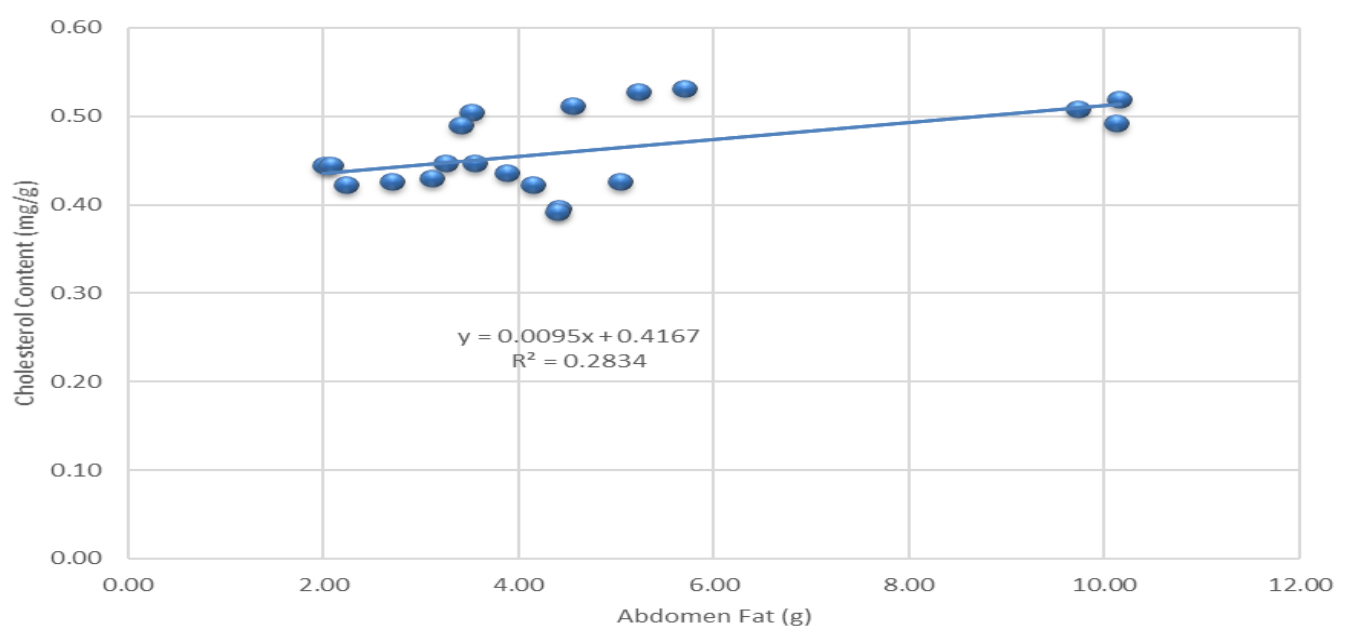

$(P<0.05)$

Figure 2. Relating cholesterol content and the weight of abdomen fat local chicken administrated various feed additives.

\section{Relating Cholesterol Content and Abdomen Fat}

The result of linier regression analysis relating cholesterol content and the weight of abdomen fat was presented in Figure 2. The result of the study indicated that low correlation between abdomen fat and cholesterol content local chicken fed various feed additives with $R^{2}=28.34 \%$ with the line equation of $Y=0.009 \mathrm{X}+0.416$. It had weak positive correlation in which increased $0.0095 \mathrm{~g}$ of abdomen fat increased $0.416 \mathrm{mg} / \mathrm{g}$ cholesterol. Based on determination values indicated that $28.3 \%$ reducing of cholesterol influenced by fat abdomen and the rest was effected by other factors. According to Pfaff and Austic (1976) abdomen fat had correlation with carcass, the higher abdomen fat was the higher carcass fat. The concentration of fat in the animal body was influenced by feed and available energy in the feed.

Syzka et al. (2009) stated that accumulation of abdomen fat and spread in the body was influenced by feed. Gultom et al. (2012) informed that abdomen fat tented to go up with the increase of body weight. In addition, other factor affected abdomen fat age, sex, breed and animal production management. This is in accordance with Yuniza (2002) stated that fat content increased with the age and female animals deposited fat was faster than male animals.

\section{Conclusions}

In conclusion, based on the results of the study concluded that administration of various feed additives was be able to reduce cholesterol content and the percentage of fat abdomen with the lowest of cholesterol content $43 \mathrm{mg} / 100 \mathrm{~g}$ and the lowest percentage of fat abdomen $0.27 \%$ for prebiotic treatment.

\section{Acknowledgement}

This study was supported by Ministry of Research and Technology Higher Education under applied product research in 2017. Authors thanks to group research team (Ali Makmur, M. Hanafiah and Andika Boy Yuliansyah) for good cooperation during research activities both in the field and laboratory analysis.

\section{References}

Akhadiarto S. 2010. Pengaruh pemberian probiotik temban, biovet dan biolacta terhadap persentase karkas, bobot lemak abdomen dan organ dalam ayam broiler. JSTI, 12(1): 53-59.

Baron SF and PB Hylemon. 1997. Biotransformation of bile acids, cholesterol, and steroid hormones. Gastrointestinal Microbiology. (1): 470-510.

Campbell, Mary K. and Shawn O. F. 2005. Biochemistry. (4th ed.). Singapore: Thomson Asia Pte Ltd.

Dibner JJ dan JD Richaards. 2005. Antibiotics growth promoters in agriculture. History on mode of action. Poult. Sci. 84: 634-643. 
doi:https://doi.org/10.17969/agripet.v16i1.3657

Febrisiantosa A, L Istiqomah, A Sofyan, E Damayanti, H Herdian, H Julendra dan M Angwar. 2012. Persentase karkas, kandungan lemak dan kolesterol daging ayam dengan pemberian aditif pakan mengandung bakteri asam laktat dan tepung ganoderma lucidum. Workshop Nasional Unggas Lokal. pp: 109-113.

Fontana EA, D Weaver Jr, DM Denbaow and BA Watkins. 1993. Early feed restricition of broiler: Affect on abdominal fat pad, liver and gizzard weight, fat deposition and carcas compotion. J. Poult. Sci. (72): 243-250.

Gropper SS, JL Smith and JL Groff. 2005. Advenced Nutrition and Human Metabolism. 4th ed. Wadsworth. USA.

Gultom SM, H Supratman dan Abun. 2012. Pengaruh Imbangan Energi dan Protein Ransum Terhadap bobot Karkas dan Bobot Lemak Abdominal Ayam Broiler Umur 3-5 Minggu. J. Agrik. 1(1): 1-5.

Hartono EF, N Iriyanti dan Sri Suhermiyati S. 2016. Efek Penggunaan Sinbiotik Terhadap Kondisi Miklofora dan Histologi Usus Ayam Sentul Jantan. Agripet. 16(2):97-105.

Hasanuddin S, VD Yunianto, dan Tristiarti. 2013. Lemak dan kolesterol daging pada ayam broiler yang diberi pakan step down protein dengan penambahan air perasan jeruk nipis sebagai acidifier. Buletin Nutrisi dan makanan Ternak. 9(1): 47-53.

Ibrahim W, R Mutia, Nurhayati, Nelwida dan Berliana. 2016. Penggunaan Kulit Nanas Fermentasi dalam Ransum yang Mengandung Gulma Berkhasiat Obat Terhadap Konsumsi Nutrient Ayam Broiler. Agripet. 16(2): 76-82.

Ihsan FN. 2006. Persentase Bobot Karkas, Lemak Abdomen dan Organ dalam Ayam Broiler Dengan Pemberian Silase Ransum Komersial. Skripsi. Fakultas Peternakan Institut Pertanian Bogor, Bogor.

Jang, I.S., KoS., Y.H., Kang, Y and C.Y.Lee. 2007. Effect of a commercial essential oil on growth performance, digestive enzyme activity and intestinal microflora population in broiler chicken. Animal Feed Science and Technology. Volume 134, Issues 3-4, 2 : 304-315.

Koenan, M.E; J. Kramer, R. van der Hulst, L. Heres, S.H.M. Jeurissen and W.J.A. Boersma. Immunomodulation by probiotic lactobacilli in layer- and meat-type chicken. British Poultry Science. Vol 45, No. 3: 355-366.

Liang OB, Y Apsarton, T Widjaya dan S Puspa. 1985. Isolasi, aspek-aspek identifikasi komponen curcuma xanthorrhiza roxb. dan Curcuma domestica val. Prosiding Simposium Nasional Temulawak. Bandung, 17 September 1985. Bandung. Hal. 85.
Linder MC. 2006. Biokimia Nutrisi dan Metabolisme. Jakarta: UI Press.

Mangisah I. 2003. Ilmu Nutrisi dan Makanan Ternak Babi. Diktat Kuliah. Fakultas Pertanian Universitas Diponegoro. Semarang.

Mide MZ. 2014. Pemanfaatan temulawak (Curcuma xanthorrhiza roxb) dalam ransum sebagai upaya menurunkan lemak abdominal dan kolesterol darah broiler. JITV. 19(2): 572-575.

Nurhayati, Berliana dan Nelwida. 2016. Performa Ayam Broiler yang Mengkonsumsi Kulit Nanas yang Difermentasi dengan Yogurt dalam Ransum Mengandung Gulma Obat. Agripet. 16(1): 31-36.

Ooi LG and MT Liong. 2010. Cholesterol-lowering effects of probiotics and prebiotics: a review of in vivo and in vitro findings. International journal of molecular sciences. 11(6): 2499-2522.

Pfaff JrFE, and RE Austic, 1975. Influence of diet on development of the abdominal fat pad in the pullet. J. Nutr. 106(3): 443-450.

Poendjiadi A. 2005. Dasar-Dasar Biokimia. UI Press. Jakarta.

Purseglove JW, EG Brown, CL Green and SRJ Robbins. 1981. Pepper Spices. Longman, London and New York. p. 10-99.

Saidin M. 2000. Kandungan kolesterol dalam berbagai bahan makanan hewani. Bul. Penelit. Kesehat. 27(2): 224-230. doi:10.22435/bpk.v27i2 Jun. 305.

Santoso U dan K Tanaka.1995. Effect of dried bacillus subtilis culture on growth, body composition and hepatic lipogenic enzyme activity in female ayam kampung chicken. Brit. J. Nutr.74(4): 523-529.

Setiawan I dan E Sujana. 2009. Bobot akhir, persentase karkas dan lemak abdominal ayam broiler yang dipanen pada umur yang berbeda. Seminar Nasional Fakultas Peternakan Universitas Padjajaran. Bandung.

Sitepoe M. 1993. Kolesterol Fobia Keterkaitannya dengan Penyakit Jantung. PT. Gramedia Pustaka Utama, Jakarta.

Surono IS, 2004. Probiotik Susu Fermentasi dan Kesehatan. Tri Cipta Karya: Jakarta

Sutama INS, TGO Susila, SA Lindawati, RR Indrawati dan INA Tirta. 2010. Pengaruh penggunaan prebiotik dalam ransum terhadap profil lipid serum dan kolesterol daging ayam kampong. Makalah Ilmiah Peternakan. 13(3): 103-106.

Syzka MG, H Supratman dan Abun. 2009. Pengaruh imbangan energi dan protein pakan terhadap bobot karkas dan bobot lemak abdominal ayam broiler umur 3-5 minggu. J. Agroland. 16(1): 105112.

Torres-Rodriguez ASE, JLS Higgins, AD Vicente, G Wolfenden, JT Gaona-Ramirez, G Barton, AM Tellez, BM Donoghue and Hargis. 2007. Effect of Lactose as a Prebiotic on Turkey Body Weight 
Under Commercial Conditions. The Journal of Applied Poultry Research, Volume 16, Issue :635641,

Wiryawan KG, M Sriasih, IDP Winata. 2005. Penampilan Ayam Pedaging yang Diberi Probiotik (EM-4) Sebagai Pengganti Antibiotik. Fakultas Peternakan, Universitas Mataram, Mataram NTB.
Witantra. 2011. Pengaruh Pemberian Lisin dan Metionin Terhadap Persentase Karkas dan Lemak Abdominal pada AyamPedaging Asal Induk Bibit Muda dan Induk Bibit Tua. Artikel Ilmiah. Universitas

Airlangga. Surabaya. 